Original Paper

Juntendo Medical Journal

2010. $56(2), 100 \sim 106$

\title{
Japan-Indonesia Collaborative Study of Imidapril on Antiproteinuric Effect in Hypertensive Patients with Chronic Kidney Disease (CKD)
}

\author{
Toshinao TSUGE*1) \\ Atsushi KURUSU*1) \\ Yoshio SHIMIZU*1) \\ Ginova NAINGGOLAN*2) \\ Chandra MOHANI*3) \\ RIZANIANSYAH*3)
}

\author{
Wiguno PRODJOSUDJADI*2) \\ IsAo OHSAWA*1) \\ SUHARDJONO *2) \\ AIDA LIDYA*2) \\ Dлоко SANTOSO*3) \\ SATOSHI HORIKOSHI*1)
}

\author{
Mohammad YOGIANTORO *3) \\ Noriyoshi KOBAYASHI*1) \\ DHARMEIZAR*2) \\ PRANAWA*3) \\ WIDODO*3)
}

YASUHIKo TOMINO*1)

Background : Chronic kidney disease (CKD) is a comprehensive disease concept that includes chronic glomerulonephritis such as IgA nephropathy or lupus nephritis, diabetic nephropathy and hypertensive nephrosclerosis. CKD is a risk factor for end stage kidney disease (ESKD) and cardiovascular diseases (CVD). It is considered that angiotensin-converting enzyme (ACE) inhibitors and angiotensin II receptor blockers (ARBs) induce a marked renoprotective effect in patients with CKD. The purpose of the present Japan-Indonesia collaborative study was to evaluate the antiproteinuric effect of imidapril, one of the ACEIs, in hypertensive patients with CKD.

Methods: Twenty three hypertensive CKD patients were treated with imidapril and a calcium channel blocker (CCB). Imidapril was added for patients who had been treated with a CCB such as diltiazem at the start of this study. When blood pressure (BP) did not reach the target level $(<130 / 85 \mathrm{mmHg})$, imidapril dosage was increased to $10 \mathrm{mg} /$ day and administered for 12 months. Alternatively, patients were treated with 5-10 mg/day of imidapril.

Results : In the imidapril + CCB combination therapy, systolic blood pressure (SBP) and diastolic blood pressure (DBP) were significantly reduced, both at 6 months and at the end of the clinical study. Only DBP reached values below the target level. Urinary albumin excretion (UAE) levels were markedly decreased at 6 and 12 months when compared with the baseline values $(0.45 \pm 0.54 \mathrm{~g} / \mathrm{g} \cdot \mathrm{Cr}$ indicating typical overt proteinuria) and these decreases at both time points were significant. The UAE levels at both 6 and 12 months complied with the diagnostic criteria for microalbuminuria $(<0.299 \mathrm{~g} / \mathrm{g} \cdot \mathrm{Cr})$.

Conclusion : In this collaborative study, a combination of imidapril and a CCB, such as diltiazem, significantly reduced BP, and reduced UAE, suggesting strict BP control may induce an efficient decrease in UAE. It appears that imidapril-based therapy has renoprotective effects in hypertensive patients with CKD.

Key words : proteinuria, blood pressure, imidapril (ACE inhibitor), CKD, Japan-Indonesia

* 1) Division of Nephrology, Department of Internal Medicine, Juntendo University School of Medicine, Tokyo, Japan

* 2) Nephrology Division, Department of Internal Medicine, Indonesia University, Jakarta, Indonesia

* 3) Nephrology Division, Department of Internal Medicine, Airlangga University, Surabaya, Indonesia

〔Received Oct. 14, 2009] [Accepted Dec. 7, 2009〕 


\section{Introduction}

Chronic Kidney Disease (CKD) is a comprehensive disease concept that includes chronic glomerulonephritis such as IgA nephropathy or lupus nephritis, diabetic nephropathy and hypertensive nephrosclerosis, as well as a variety of renal diseases including but not limited to dialysis and kidney transplantation ${ }^{1)}$. The concept of CKD has recently been proposed and is steadily spreading as a new condition jeopardizing the human health ${ }^{2}$. In Japan, comprehensive CKD measures have been inclusively taken on Japanese Society of Nephrology, and also, Asian countries have been taken steps to against CKD. However, the research works is not enough in Asian countries, especially Southeast Asian countries. The purpose of the present study is to activate the CKD clinical research in Indonesia through this collaborative study.

As it progresses, CKD induces histological renal changes that are usually irreversible and cause glomerulosclerosis and tubular interstitial fibrosis, leading to end stage kidney disease (ESKD). High risk groups for CKD requiring particular attention include those with diabetes mellitus, hypertension, metabolic syndrome, obesity, cigarette smoking, family history of CKD and dyslipidemia ${ }^{3)}$. In CKD patients, hypertension occurs with high frequency as a complication, and hypertension itself, as in the case of proteinuria or decreased GFR, is a strong risk factor for progression of renal function impairment $^{4) 5}$. On the other hand, hypertension is also a strong risk factor for development and progression of cardiovascular diseases (CVD) ${ }^{6}$. To break this vicious spiral, it is necessary to start proactive control of blood pressure (BP) early in the management of CKD.

Clinical practice guidelines for management of hypertension in Japan (JSH 2004) ${ }^{7}$, Europe (ESH/ ESC 2007) ${ }^{8)}$, and the USA (JNC7) ${ }^{9)}$ recommend ACE inhibitors or ARBs as first-line therapy on the basis of results of large-scale clinical studies such as $\mathrm{AASK}^{10)}$ and RENAAL ${ }^{11)}$. Imidapril hydrochloride is a long-acting ACE inhibitor with no sulfhydryl group, for which renoprotective effects, including reduction of proteinuria, have been dem- onstrated in Dahl rats ${ }^{12)}$ and in rats given NOS inhibitors ${ }^{13)}$. Furthermore, in clinical trials conducted in Japan, imidapril has been shown to prevent the increase of UAE in micro- and macroalbuminuric patients with type 1 diabetes mellitus with the target BP set at less than $130 / 80 \mathrm{mmHg}^{14)}$. With this background, we evaluated renoprotective effects of imidapril in CKD patients by investigating systolic and diastolic blood pressure (SBP/DBP), UAE and serum creatinine $(\mathrm{sCr})$ in a Japan- Indonesia Collaborative Study. Since hypertension that occurs as a complication of CKD is known to be serious and refractory, monotherapy frequently fails to reduce BP to the target levels. Given this concern, and in expectation of effects beyond BP lowering, imidapril was administered in combination with a CCB.

\section{Patients and Method}

\section{Patients}

This study was conducted in Japan and Indonesia in accordance with the principles of the Declaration of Helsinki. All CKD (stage 1-3) ${ }^{3)}$ patients provided informed consent after receiving a detailed explanation of the study. Twenty three patients (male 10 patients, female 10 patients and unknown 3 patients) with a mean age of $60.5 \mathrm{y}$. o were enrolled. Among them, 16 patients were nondiabetes and 7 patients were diabetes mellitus. Further, 7 patients were at Juntendo University, 6 patients at Indonesia University, and 10 patients at Ailangga University. The course of study parameters at baseline and after completion of treatment (from 6 months to 12 months) is shown in Table-1.

Study subject selection was conducted based on screening of laboratory data, medical histories and current medical status. These patients who met the following inclusion criteria but none of the exclusion criteria were ultimately enrolled : a history of hypertension $(130 \leq$ sitting $\mathrm{SBP}<180 \mathrm{mmHg}, 85 \leq$ sitting $\mathrm{DBP}<110 \mathrm{mmHg})$; serum creatinine $(\mathrm{sCr})$ $<2.0 \mathrm{mg} / \mathrm{dL}$; and urinary albumin excretion (UAE) $<1 \mathrm{~g} / 24 \mathrm{hrs}$. The exclusion criteria included patients with contraindications such as pregnancy, renovascular hypertension, or angioma ; need for careful administration of ACE inhibitors or ARBs such as patients with severe hyperten- 
Table-1 Characteristics of 23 chronic kidney disease patients who received imidapril withCCB

\begin{tabular}{lcc}
\hline & & $($ Mean \pm SD $)$ \\
\hline Age $(\mathrm{yrs})$ & $60.5 \pm 10.5$ \\
Blood pressure $(\mathrm{mmHg})$ & \\
& SBP & $147 \pm 14$ \\
& $\mathrm{DBP}$ & $87 \pm 10$ \\
Urinary albumin excretion $(\mathrm{g} / \mathrm{g} \cdot \mathrm{Cr})$ & $0.45 \pm 0.54$ \\
Serum creatinine $(\mathrm{mg} / \mathrm{dL})$ & $1.01 \pm 0.36$ \\
\hline
\end{tabular}

CCB: calcium channel blocker

Table-2 Effects of imidapril + CCB therapy on blood pressure (BP) and renal function in 21 chronic kidney disease patients

\begin{tabular}{lcccc}
\hline & $\begin{array}{c}\text { SBP } \\
(\mathrm{mmHg})\end{array}$ & $\begin{array}{c}\mathrm{DBP} \\
(\mathrm{mmHg})\end{array}$ & $\begin{array}{c}\mathrm{UAE} \\
(\mathrm{g} / \mathrm{g} \cdot \mathrm{Cr})\end{array}$ & $\begin{array}{c}\mathrm{sCr} \\
(\mathrm{mg} / \mathrm{dL})\end{array}$ \\
\hline Baseline & $147 \pm 14$ & $87 \pm 10$ & $0.45 \pm 0.54$ & $1.01 \pm 0.36$ \\
6 month & $135 \pm 14^{*}$ & $80 \pm 8^{*}$ & $0.20 \pm 0.30^{*}$ & $1.03 \pm 0.34$ \\
12 month & $133 \pm 16^{*}$ & $80 \pm 8^{*}$ & $0.15 \pm 0.26^{*}$ & $1.07 \pm 0.35$ \\
\hline & & CCB:calcium channel blocker \\
& & & SBP:systolic blood pressure \\
& & & DBP:diastolic blood pressure \\
& & & UAE: Urinary Albumin Excretion \\
& & & sCr:Serum Creatinine
\end{tabular}

sion ; patients who undergo hemodialysis ; patients on diuretic therapy (especially those in whom diuretic therapy has been recently initiated); patients on strict dietary salt restriction; diabetic patients with obviously poor glucose control $(\mathrm{HbAlc} \geq 10 \%)$ and patients judged by the attending physician to be inappropriate, i. e. patients with kidney transplantation or proteinuria $>1.0 \mathrm{~g} / 24$ hrs.

\section{Treatment protocol}

Twenty three patients were treated with imidapril and CCB. Imidapril was added for patients who had been treated with a CCB such as diltiazem at the start of this study. When BP did not reach the target level $(<130 / 85 \mathrm{mmHg})$, imidapril dosage was increased to $10 \mathrm{mg} /$ day and administered for 12 months. Alternatively, patients were first treated with 5-10 mg/day of imidapril. In principle, antihypertensive drugs such as diuretics, which had been prescribed before this study, were not changed during the study. All patients in this study underwent bi-monthly laboratory check-ups throughout the $12-$ month study period.

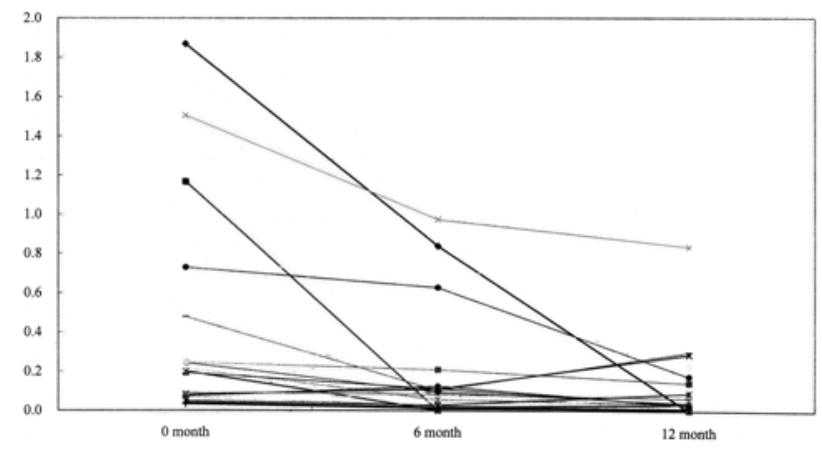

Figure-1 UAE levels were markedly decreased at 6 and 12 months when compared with the baseline values $(\mathrm{p}<0.05)$.

\section{Evaluation and Measurement}

At 2 weeks before initiation of the study (baseline) and at the beginning of every 2 -month period, SBP/DBP, $\mathrm{sCr}$ and UAE were measured in each patient. BP was measured using a mercury sphygmomanometer with the patient in the sitting position.

\section{Statistical analysis}

Results are expressed as means $\pm \mathrm{SD}$. Paired $\mathrm{t}^{-}$ test and two-way ANOVA were used to evaluate changes from baseline of $\mathrm{sCr}$, UAE, and SBP/DBP. $\mathrm{P}$ values $<0.05$ were considered significant.

\section{Results}

In the imidapril $+\mathrm{CCB}$ combination therapy, the average SBP and DBP at baseline were $147 \pm 14$ $\mathrm{mmHg}$ and $87 \pm 10 \mathrm{mmHg}$, respectively. SBP and DBP were significantly reduced, both at 6 months and at the end of the clinical study at 12 months. Only DBP reached values below the target level (Table-2).

In the imidapril + CCB combination therapy, UAE levels were markedly decreased at 6 and 12 months when compared with the baseline values $(0.45 \pm 0.54 \mathrm{~g} / \mathrm{g} \cdot \mathrm{Cr}$ indicating typical overt proteinuria) and these decreases at both time points were significant. The UAE levels at both 6 and 12 months complied with the diagnostic criterion for microalbuminuria $(<0.299 \mathrm{~g} / \mathrm{g} \cdot \mathrm{Cr})$ based on quantitative evaluation of spot urine samples as proposed 
by the Japanese CKD guidelines ${ }^{15}$. $\mathrm{sCr}$ showed no significant changes (Fig-1)

\section{Discussion}

In Japan, definitions of CKD were published in the Clinical Practice Guidelines for Diagnosis and Treatment of CKD (2007) and the Clinical Practice Guidelines for Diagnosis and Treatment of CKD With Special Reference to Hypertension (2008). The first objective of the present Japan-Indonesia Collaborative Study was used to follow the progression of renal function impairment. The following measures have been proposed to prevent CKD from progressing to end stage kidney disease (ESKD) : 1) lifestyle modification (improvements in obesity, dyslipidemia and hyperglycemia), 2) diet therapy, 3) control of hypertension, 4) suppression of the renin-angiotensin system (RAS), 5) improvement of anemia, and 6) elimination of uremic toxins ${ }^{3}$. Among these measures, the RAS plays an important role in regulating BP. Blockade of the RAS with ACE inhibitors or ARBs has been shown to be effective treatment for hypertension ${ }^{16)}{ }^{17}$.

Independent of their ability to lower BP, these agents have also been reported to be associated with the progression of nephropathy in patients with diabetes mellitus and chronic renal failure ${ }^{18 \sim 21}$. Although the guidelines for the management of hypertension ${ }^{7) \sim 9)}$ recommend that BP should be strictly controlled in hypertensive patients with renal diseases, adequate BP levels are not often achieved with RAS inhibitor monotherapy. A combination of two to three antihypertensive agents is required to decrease $\mathrm{BP}$ to target levels, especially in patients with renal diseases ${ }^{22}$. The main candidates for combination with a RAS inhibitor include CCBs, since they reduce BP even in patients who are considered resistant to other antihypertensive agent $^{23}$. In addition, it is known that non-dihydropiridine (DHP) CCBs such as diltiazem show $\mathrm{BP}$ independent renoprotective effects ${ }^{24)}$. Especially in patients with diabetes, nifedipine significantly increased proteinuria and significantly decreased creatinine clearance $(\mathrm{CCr})$ when compared with diltiazem ${ }^{25)}$. In another study, diltiazem decreased proteinuria in patients with diabetes and its effect was similar to that of lisinopril ${ }^{26)}$. Therefore, a more potent renoprotective effect may be achieved with imidapril with diltiazem. Imidapril is a versatile ACE inhibitor that has been used clinically in the treatment of hypertension, chronic congestive heart failure and acute myocardial infarction ${ }^{27}$. In addition, imidapril, like other ACE inhibitors, alleviates renal injuries in rat models of various types of nephropathy ${ }^{12)}{ }^{28)}$, and has been shown to inhibit renal ACE activity more potently than captopril or enalapril $^{29) \sim 31}$. Therefore, imidapril may have advantages over other antihypertensive agents in protecting against renal damage. The Guidelines for Management of Hypertension 2009 (JSH 2009) ${ }^{32}$ ) recommend that even in patients with high-normal BP of 130-139/85-89 mmHg, the presence of $\mathrm{CKD}$ and diabetes mellitus requires application any effective antihypertensive therapy to maintain $\mathrm{BP}$ at normal levels. According to the Clinical Practice Guidelines for Diagnosis and Treatment of CKD, with Special Reference to Hypertension $(2008)^{15)}$, the target BP for antihypertensive treatment in CKD patients with hypertension as a complication is $<130 / 80 \mathrm{mmHg}$, and is even lower $(<$ $125 / 75 \mathrm{mmHg}$ ) if proteinuria is $\geq 1 \mathrm{~g} /$ day.

We evaluated the results of this collaborative study based on disease conditions to be treated and target BP for antihypertensive treatment recommended by both of the above-mentioned guidelines, i. e. JSH 2009 Guidelines and Clinical Practice Guidelines for CKD. In the imidapril + CCB combination therapy, the baseline SBP/DBP of the combination therapy group on the whole was $147 \pm 14$ $/ 87 \pm 10 \mathrm{mmHg}$, which satisfied the conditions requiring treatment proposed by the two guidelines, and met the inclusion criteria of the collaborative study. The baseline UAE level was $0.45 \pm 0.54 \mathrm{~g} /$ $\mathrm{g} \cdot \mathrm{Cr}$, which clearly indicated overt proteinuria. The average SBP/DBP values at 6 and 12 months after the start of combination therapy were135 \pm $14 / 80 \pm 8$ and $133 \pm 16 / 80 \pm 8 \mathrm{mmHg}$, respectively. Both SBP and DBP were significantly reduced, although only DBP reached the target BP level for CKD $(<130 / 80 \mathrm{mmHg})$ at both 6 and 12 months. The significant reduction in DBP at both 6 and 12 months after the start of combination therapy was reflected in $\mathrm{UAE}$, which was significantly decreased to $0.20 \pm 0.30$ and $0.15 \pm 0.26 \mathrm{~g} / \mathrm{g} \cdot \mathrm{Cr}$, respectively. Thus, improvement from overt protei- 
nuria to microalbuminuria was clearly noted Shigihara et al. ${ }^{33)}$ demonstrated that in hypertensive microalbuminuric type 2 diabetic patients, the combination of an ACE inhibitor (including imidapril) and a CCB (amlodipine) resulted in marked reduction in $\mathrm{BP}(\mathrm{DBP}<80 \mathrm{mmHg})$ and greater decrease in UAE than use of an ACE inhibitor alone. Our results were a consistent with this finding and in the Collaborative Study imidapril with $\mathrm{CCB}$ combination therapy exerted a greater antiproteinuric effect than imidapril alone in the CKD subgroup in which DBP fell below the target level (data not shown). Recently, much attention has been paid to the strategy for prevention of the progression of CKD. By accumulating data from a large number of clinical mega-trials, we have witnessed the beneficial action of ACE inhibitors ${ }^{20)}{ }^{34)}{ }^{35}$ ). On the basis of previously reported findings on efficacy of an ACE inhibitor and CCB combination strategy for the management of $\mathrm{CKD}^{33)}{ }^{36)}$, , together with the results of this collaborative study, a CCB may be the best candidate for combination with an $\mathrm{ACE}$ inhibitor for the treatment of CKD.

In this collaborative study, combination treatment with imidapril and a CCB, such as diltiazem, significantly reduced $\mathrm{BP}$, and reduced UAE, suggesting that strict BP control may induce an efficient decrease in UAE. In addition, the level of serum creatinine $(\mathrm{sCr})$ did not increase during this study. It appears that imidapril-based therapy has renal protective effects in patients with various chronic kidney diseases. Further study which is controlled, double-blinded and randomized with larger number of patients is necessary to investigate ACE-I + CCB combination for treatment of CKD.

Financial support : This study was supported by Mitsubishi Tanabe Co. Ltd. , Japan and Tanabe Indonesia, Indonesia.

Conflict of interest statement: None declared.

\section{References}

1) National Kidney Foundation : K/DOQI clinical practice guidelines for chronic kidney disease : evaluation, classification, and stratification. Am J Kidney Dis, 2002 ; 39 : $\mathrm{S} 1 \sim \mathrm{S} 226$.
2) Go AS, Chertow GM, Fan D, et al : Chronic kidney disease and the risks of death, cardiovascular events, and hospitalization. N Engl J Med, 2004 ; 351 : 1296 1305.

3) Japanese Society of Nephrology: Clinical practice guidebook for diagnosis and treatment of Chronic Kidney Disease, Tokyo : Tokyo Igakusha ; 2007.

4) Yamagata K, Ishida K, Sairenchi T, et al : Risk factors for chronic kidney disease in a community-based population: a 10-year follow-up study. Kidney Int, 2007 ; $71: 159 \sim 166$.

5) Bakris GL, Williams M, Dworkin L, et al : Preserving renal function in adults with hypertension and diabetes : a consensus approach. National Kidney Foundation Hypertension and Diabetes Executive Committees Working Group. Am J Kidney Dis, 2000 ; $36: 646 \sim 661$.

6) Sarnak MJ, Levey AS, Schoolwerth AC, et al : Kidney disease as a risk factor for development of cardiovascular disease : a statement from the American Heart Association Councils on Kidney in Cardiovascular Disease, High Blood Pressure Research, Clinical Cardiology, and Epidemiology and Prevention. Circulation, $2003 ; 108$ : 2154 2169.

7) Guideline Subcommittee : Japanese Society of Hypertension guideline for the Management of Hypertension (JSH 2004). Hypertens Res, $2004 ; 25: 1 \sim 105$.

8) Grupo de Trabajo para el Tratamiento de la Hipertensión Arterial de la Sociedad Europea ; Sociedad Europea de Cardiología, Mancia G, De Backer G, et al : ESH/ ESC 2007 Guidelines for the management of arterial hypertension. Rev Esp Cardiol, 2007 ; 60 : 968.e1 94.

9) Chobanian AV, Bakris GL, Black HR, et al: The Seventh Report of the Joint National Committee on Prevention, Detection, Evaluation, and Treatment of High Blood Pressure : the JNC 7 report. JAMA, 2003 ; 289 : 2560 2572.

10) Douglas JG, Agodoa L : ACE inhibition is effective and renoprotective in hypertensive nephrosclerosis : the African American Study of Kidney Disease and Hypertension (AASK) trial. Kidney Int Suppl, 2003 ; 83 : S74 S76.

11) Keane WF, Brenner BM, de Zeeuw D, et al : The risk of developing end-stage renal disease in patients with type 2 diabetes and nephropathy : the RENAAL study. Kidney Int, $2003 ; 63:$ 1499 1507.

12) Yoneda $H$, Toriumi $W$, Ohmachi $Y$, et al : Involvement of angiotensin II in development of spontaneous nephrosis in Dahl salt-sensitive rats. Eur J Pharmacol, 1998 ; $362: 213 \sim 219$.

13) Kashiwagi M, Shinozaki M, Hirakata H, et al : Locally activated renin-angiotensin system associated with 
TGF-betal as a major factor for renal injury induced by chronic inhibition of nitric oxide synthase in rats. $\mathrm{J}$ Am Soc Nephrol, $2000 ; 11: 616 \sim 624$.

14) Katayama S, Kikkawa R, Isogai $S$, et al : Effect of captopril or imidapril on the progression of diabetic nephropathy in Japanese with type 1 diabetes mellitus : a randomized controlled study (JAPAN-IDDM). Diabetes Res Clin Pract, $2002 ; 55:$ 113 121.

15) Japanese Society of Nephrology : CKD Therapeutic Guideline, Tokyo : Tokyo Igakusha ; 2008.

16) Suzuki $\mathrm{H}:$ Treatment of hypertension in chronic renal insufficiency. Intern Med, 2000 ; 39 : 773 777.

17) Suzuki $H$ : Angiotensin type 1 receptor blockers in chronic kidney disease. Contrib Nephrol, 2004 ; 143 : 159 166 .

18) Lewis EJ, Hunsicker LG, Bain RP, et al : The effect of angiotensin-converting-enzyme inhibition on diabetic nephropathy. The Collaborative Study Group. N Engl J Med, 1993 ; 329 : 1456 1462.

19) Brenner BM, Cooper ME, de Zeeuw D, et al : Effects of losartan on renal and cardiovascular outcomes in patients with type 2 diabetes and nephropathy. N Engl J Med, $2001 ; 345:$ 861 869.

20) Ruggenenti P, Perna A, Gherardi G, et al : Renoprotective properties of ACE-inhibition in non-diabetic nephropathies with non-nephrotic proteinuria. Lancet, 1999 ; $354: 359 \sim 364$.

21) Kanno Y, Okada H, Yamaji Y, et al : Angiotensin-converting-enzyme inhibitors slow renal decline in IgA nephropathy, independent of tubulointerstitial fibrosis at presentation. QJM, $2005 ; 98$ : 199 203.

22) Koshy S, Bakris GL: Therapeutic approaches to achieve desired blood pressure goals : focus on calcium channel blockers. Cardiovasc Drugs Ther, $2000 ; 14$ : 295 301.

23) Kloke HJ, Branten AJ, Huysmans FT, et al : Antihypertensive treatment of patients with proteinuric renal diseases : risks or benefits of calcium channel blockers? Kidney Int, $1998 ; 53:$ 1559 1573.

24) Tarif N, Bakris GL : Preservation of renal function : the spectrum of effects by calcium-channel blockers. Nephrol Dial Transplant, $1997 ; 12: 2244 \sim 2250$.

25) Demarie BK, Bakris GL : Effects of different calcium antagonists on proteinuria associated with diabetes mellitus. Ann Intern Med, $1990 ; 113$ : 987 988.

26) Bakris GL : Effects of diltiazem or lisinopril on massive proteinuria associated with diabetes mellitus. Ann Intern Med, 1990, $112:$ 707 708.

27) Hosoya K, Ishimitsu $T$ : Protection of the cardiovascular system by imidapril, a versatile angiotensin-converting enzyme inhibitor. Cardiovasc Drug Rev, 2002 ; 20 : 93 110.

28) Akuzawa N, Nakamura T, Kurashina T, et al : Antihypertensive agents prevent nephrosclerosis and left ventricular hypertrophy induced in rats by prolonged inhibition of nitric oxide synthesis. Am J Hypertens, 1998 ; $11: 697 \sim 707$.

29) Sugaya $T$, Minobe S, Taniguchi T, et al : Studies on angiotensin I converting enzyme (ACE) inhibitory effect of imidapril. (I). Inhibition of various tissue ACEs in vitro. Nippon Yakurigaku Zasshi, $1992 ; 100: 39 \sim 45$.

30) Hashimoto Y, Kubo M, Sugaya T, et al : Studies on angiotensin I converting enzyme (ACE) : inhibitory effect of imidapril, a novel ACE inhibitor (II). Inhibition of various tissue ACEs ex vivo. Nippon Yakurigaku Zasshi, 1994 ; $104: 51 \sim 61$.

31) Katoh M, Ohmachi Y, Kurosawa Y, et al : Effects of imidapril and captopril on streptozotocin-induced diabetic nephropathy in mice. Eur J Pharmacol, 2000 ; 398 : $381 \sim 387$.

32) Guideline Subcommittee. Japanese Society of Hypertension : Guideline for the Management of Hypertension (JSH 2009), $2009:$ 14 17.

33) Shigihara T, Sato A, Hayashi K, et al : Effect of combination therapy of angiotensin-converting enzyme inhibitor plus calcium channel blocker on urinary albumin excretion in hypertensive microalbuminuric patients with type II diabetes. Hypertens Res, $2000 ; 23: 219 \sim 226$.

34) Lewis EJ, Hunsicker LG, Bain RP, et al: The effect of angiotensin-converting-enzyme inhibition on diabetic nephropathy. The Collaborative Study Group, N Engl J Med, 1993 ; 329 : 1456 1462.

35) Maschio G, Alberti D, Janin G, et al : Effect of the angiotensin-converting-enzyme inhibitor benazepril on the progression of chronic renal insufficiency. The Angiotensin-Converting-Enzyme Inhibition in Progressive Renal Insufficiency Study Group. N Engl J Med, 1996 ; 334 : 939 945.

36) Hayashi K, Kumagai H, Saruta $\mathrm{T}$ : Effect of efonidipine and ACE inhibitors on proteinuria in human hypertension with renal impairment. Am J Hypertens, 2003 ; $16: 116 \sim 122$.

37) Fujita $T$, Ando K, Nishimura $H$, et al : Antiproteinuric effect of the calcium channel blocker cilnidipine added to renin-angiotensin inhibition in hypertensive patients with chronic renal disease. Kidney Int, 2007 ; 72 : 1543 1549 . 


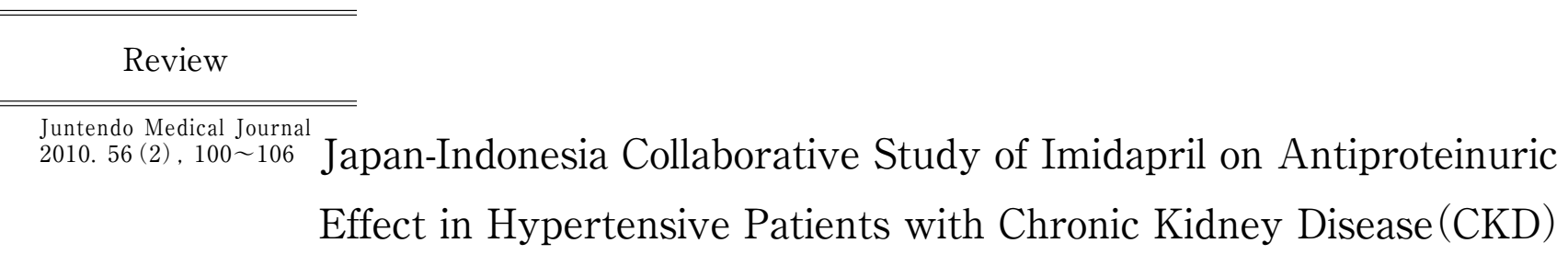

\title{
CKD 患者におけるイミダプリルの尿虫白減少効果
}

\author{
（日本一インドネシア共同研究）
}

\author{
柘 植 俊 直 \\ Toshinao TSUGE \\ 来栖厚 \\ Atsushi KURUSU \\ 清 水 芳 男 \\ Yoshio SHIMIZU
ジノヴァ ナインゴラン
Ginova NAINGGOLAN
チャンドラ モハニ
CHANDRA MOHANI
リザニアンシャ
RIZANIANSYAH

ウィグノ プロドジョスドジャジ Wiguno PRODJOSUDJADI

$$
\begin{gathered}
\text { 大 澤 勲 } \\
\text { IsAO OHSAWA } \\
\text { スハードジョノ } \\
\text { SUHARDJONO } \\
\text { アイーダ リージャ } \\
\text { AIDA LIDYA } \\
\text { ジョーコ サントソ } \\
\text { DJoKo SANTOSO } \\
\text { 堀 越 哲 } \\
\text { SATOSH HORIKOSHI }
\end{gathered}
$$

モハマド ヨギアントロ Mohammad YOGIANTORO

小 林 則 善 Noriyoshi KOBAYASHI

ダルメイザー DHARMEIZAR

$$
\begin{aligned}
& \text { プラナワ } \\
& \text { PRANAWA } \\
& \text { ウィドド } \\
& \text { WIDODO }
\end{aligned}
$$

富野康日己 YaSUHIKo TOMINO

抄 録

背景：慢性腎臟病 (CKD) は, IgA 腎症やループス腎炎などの慢性系球体腎炎, 糖尿病腎症や腎硬 化症など，全ての慢性腎臟病を含んだ疾患概念である。CKDは末期腎不全 (ESKD)の準備状態で あると同時に，心血管疾患 (CVD) の重大なリスク因子であることが明らかとなっている.アンジ オテンシン変換酵素 (ACE) 阻害薬やアンジオテンシンII 受容体拮抗薬 (ARB) は, 降圧薬として 広く用いられているが, 両薬郕の腎保護効果にも注目が集まっている。 今回, 順天堂大学とインド ネシア大学, アイルランガ大学は, 高血圧を伴う CKD患者に扔ける ACE 阻害薬イミダプリルの尿 蛋白減少効果を検討する共同研究を行った.

方法：23名の高血圧を伴う CKD 患者にカルシウム拮抗薬 (CCB) とイミダプリルを投与し, 腎機能 と尿蛋白量の変化を治療前後で比較した. CCBを投与している患者にイミダプリルを追加投与 $(5 \mathrm{mg} /$ 日) し, 血圧が目標值 $(130 / 85 \mathrm{mmHg}$ 未満)に達しなかった場合には, さらにイミダプリルを $10 \mathrm{mg} /$ まで増量し, 投与後 12 力月で評価した.

結果：CCBにイミダプリルを加えることによって，6 カ月後・12 カ月後の収縮期血圧および拡張 期血圧は有意に低下した，尿中アルブミン排泄量は，投与開始時には顕性蛋白尿レベル $(0.3 \mathrm{~g} / \mathrm{g}$. Cr以上) であったが, 6 カ月後・ 12 カ月後は共に微量アルブミン尿レベル $(0.299 \mathrm{~g} / \mathrm{g} \cdot \mathrm{Cr}$ 以下) にま で有意に滅少した。

結語：イミダプリルとCCB の併用によるCKD患者の腎保護効果を，順天堂大学とインドネシア大 学, アイルランガ大学の共同研究により検討した．イミダプリルを軸とした治療により，CKD患 者の血圧は有意に低下し，尿中アルブミン排泄量は有意に減少した，以上より，イミダプリルは高 血圧を伴う CKD患者に扔いて，腎保護的に作用することが確認された。 